\title{
Editorial: Journal of Theoretical and Applied Electronic Commerce Research - CiteScore Metric from Scopus
}

\author{
Narciso Cerpa ${ }^{1}$ and Mirjana Pejić-Bach ${ }^{2}$ \\ ${ }^{1}$ Universidad de Talca, Faculty of Engineering, Curicó, Chile, ncerpa@utalca.cl \\ Editor-in-Chief \\ 2University of Zagreb, Faculty of Economics \& Business, Department of Informatics, Zagreb, Croatia, \\ mpejic@efzg.hr
}

Co-Editor

September 2018

\section{Introduction to CiteScore Metric from Scopus}

This is the third issue of the thirteenth volume of the Journal of Theoretical and Applied Electronic Commerce Research (JTAER). In this editorial we present you the CiteScore metrics from Scopus (Site 1). The CiteScore is calculated as follows:

$$
\text { CiteScore year } \mathrm{X}=\text { Citation count year } \mathrm{X} / \text { Source documents published between year }(\mathrm{X}-3) \text { and year }(\mathrm{X}-1)
$$

For example, CiteScore 2017 counts the citations received in 2017 to documents published in the period 2014 - 2016 and divides this citation count by the number of documents published in the period $2014-2016$. Therefore, it is a three-year publication window. CiteScore includes all available document types in its calculation. Therefore, both editorials and research articles are taken into account.

CiteScore 2017 = Citation count year 2017 / Source documents published between 2014 and 2016

We are continuously monitoring different quantitative metrics and we have observed that the CiteScore of JTAER has steadily increased between 2012 and 2017. The citations used for its calculation come from a variety of journals that are indexed by the Scopus (Elsevier) database. However, the number of these journals are also indexed by the Thomson Reuters (now Clarivate Analytics) in the following databases: Science Citation Index (SCI), Social Sciences Citation Index (SSCl), and the Arts and Humanities Citation Index (AHCl). This shows the relevance and acceptance of JTAER by researchers of a wide research community (see Table 1).

Table 1: CiteScore metric for period 2011 - 2017

\begin{tabular}{|c|c|c|c|c|c|c|}
\hline \multirow[t]{2}{*}{ Year $\mathrm{X}$} & \multirow{2}{*}{$\begin{array}{l}\text { Citation } \\
\text { count of } \\
\text { year } X\end{array}$} & \multirow{2}{*}{$\begin{array}{l}\text { Source } \\
\text { document } \\
\text { published } \\
\text { between year } \\
\text { X-3 and year } \\
\text { X-1 }\end{array}$} & \multirow{2}{*}{$\begin{array}{l}\text { Calculated } \\
\text { using data } \\
\text { from }\end{array}$} & \multirow[t]{2}{*}{ CiteScore } & \multicolumn{2}{|l|}{ Ranking in the category } \\
\hline & & & & & $\begin{array}{l}\text { Business, Management } \\
\text { and Accounting: General } \\
\text { Business, Management } \\
\text { and Accounting }\end{array}$ & $\begin{array}{l}\text { Computer Science: } \\
\text { Computer Science } \\
\text { Applications }\end{array}$ \\
\hline 2017 & 117 & 58 & 24 April 2018 & 2.02 & N.A. & N.A. \\
\hline 2016 & 125 & 63 & 31 May 2017 & 1.98 & $\begin{array}{l}22^{\text {nd }} / 194 \text { journals }\left(88^{\text {th }}\right. \\
\text { percentile) }\end{array}$ & $\begin{array}{l}157^{\text {th }} / 513 \text { journals } \\
\left(69^{\text {th }} \text { percentile }\right)\end{array}$ \\
\hline 2015 & 136 & 74 & 31 May 2016 & 1.84 & $\begin{array}{l}27^{\text {nd }} / 196 \text { journals }\left(86^{\text {th }}\right. \\
\text { percentile) }\end{array}$ & $\begin{array}{l}150^{\text {th }} / 498 \text { journals } \\
\left(69^{\text {th }} \text { percentile }\right)\end{array}$ \\
\hline 2014 & 92 & 81 & 31 May 2015 & 1.14 & $\begin{array}{l}41^{\text {st }} / 179 \text { journals }\left(76^{\text {th }}\right. \\
\text { percentile) }\end{array}$ & $\begin{array}{l}217^{\text {th }} / 480 \text { journals } \\
\left(54^{\text {th }} \text { percentile }\right)\end{array}$ \\
\hline 2013 & 83 & 82 & 31 May 2014 & 1.01 & $\begin{array}{l}45^{\text {th }} / 166 \text { journals }\left(73^{\text {rd }}\right. \\
\text { percentile) }\end{array}$ & $\begin{array}{l}236^{\text {th }} / 462 \text { journals } \\
\left(49^{\text {th }} \text { percentile }\right)\end{array}$ \\
\hline 2012 & 74 & 76 & 31 May 2013 & 0.97 & $\begin{array}{l}42^{\text {nd }} / 146 \text { journals }\left(71^{\text {st }}\right. \\
\text { percentile) }\end{array}$ & $\begin{array}{l}217^{\text {th }} / 440 \text { journals } \\
\left(50^{\text {th }} \text { percentile }\right)\end{array}$ \\
\hline 2011 & 109 & 77 & 31 May 2012 & 1.42 & $\begin{array}{l}28^{\text {th }} / 140 \text { journals }\left(80^{\text {th }}\right. \\
\text { percentile) }\end{array}$ & $\begin{array}{l}150^{\text {th }} / 410 \text { journals } \\
\left(63^{\text {rd }} \text { percentile }\right)\end{array}$ \\
\hline
\end{tabular}

Note: Ranking for 2017 is not yet available.

JTAER is indexed in Scopus under two categories: (i) Business, Management and Accounting: General Business, Management and Accounting, and (ii) Computer Science: Computer Science Applications, and is ranked among the top of journals in most of the observing years. For example, JTAER is ranked in 2016 as $22^{\text {nd }}$ best cited journal 
among 194 (88 ${ }^{\text {th }}$ percentile) journals in the category General Business, Management and Accounting, and $157^{\text {th }}$ best journal among 513 journals $\left(69^{\text {th }}\right.$ percentile) in the category Computer Science Applications.

The analysis of data in Table 1 shows that the year 2011 is a special case, because we had an exceptional special issue on Radio Frequency Identification (RFID) and Supply Chain Management in 2008 with high quality papers that were highly cited in 2011 and which are still cited.

This metric is updated on a monthly basis and we can keep track of the metric with the CiteScore Tracker (Site 1). This good metric value is another recognition to the quality of the research published at our journal. This important achievement would not be possible without the valuable work of all of you. We appreciate your collaboration in whatever role(s) you play: editorial board member; reviewer; author; and/or reader. We thank all of you for your great contribution to the steady development of our journal.

\section{Websites List}

Site 1: Scopus

https://www.scopus.com 